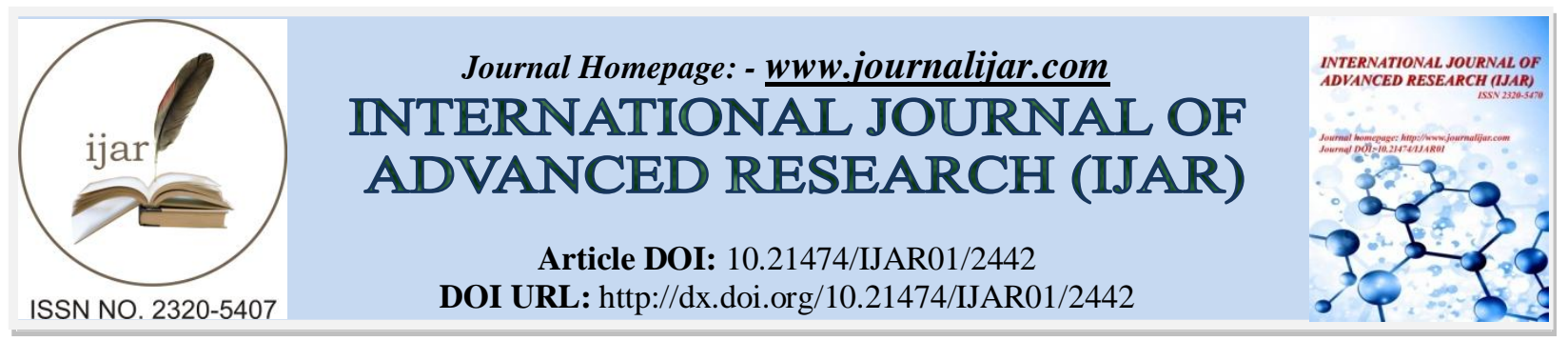

RESEARCH ARTICLE

\title{
AN ASSESSMENT OF THE LEVEL OF FEMALE PARTICIPATION IN DIFFERENT SPHERES OF LIFE IN INDIA
}

\section{Gulshan Kumar ${ }^{1}$ and Pragti Dixit ${ }^{2}$.}

1. Associate Professor in Economics at U.I.L.S., Panjab University, Chandigarh.

2. Research Scholar in the Department of Economics, Panjab University, Chandigarh.

\section{Manuscript Info}

.......................

Manuscript History

Received: 20 October 2016

Final Accepted: 22 November 2016

Published: December 2016

Key words:-

Female Participation, Well Being, Work Participation Rate, Sex Ratio.

\section{Abstract}

From the inception of life itself, women are being discriminated against men as reflected by the unequal sex ratio in India. Missing women (gender gap) and literacy gap in the majority of Indian states and even in Kerala, Lakshadweep, Goa and Tripura, the so called most literate States/U.Ts of India reveals the extent of marginalisation. A paltry share in representing the country in its national parliament, lesser work participation rate and greater vulnerability in employment mirrors their exclusion in case of resource sharing, participation and well being. Higher mortality rates, poor nutritional status, greater sterilisation rates, little information about HIV/AIDS and growing crimes against women are the key features of their life and well-being. Till date 'Say' in their own families or the decision making power is a day dream for women narrating the saga of the quality of life being led by them in India.

Copy Right, IJAR, 2016,. All rights reserved.

\section{Introduction:-}

Development can be conceived as a multi-dimensional process involving major changes in social structures, popular attitudes and national institutions, as well as the acceleration of economic growth, reduction of economic inequality and eradication of poverty (Todaro \& Smith, p. 51). Development suggests change and this is one sense in which it is used to describe the process of economic and social transformations within countries (Thirlwall, p. 19). Every nation strives to achieve gender equality to put itself on the path of development. Existing studies of intra household allocations clearly indicate that in many regions of the world, there exists a strong bias against females in areas such as nutrition, medical care, education and inheritance (Todaro \& Smith, p. 265). Progress towards the goal of gender equality is measured by examining a variety of indicators such as access to different resources, economic participation, political participation, educational attainment and quality of life and well-being. If all these indicators are evaluated in context of India, one will find the participation of women far lesser than men at every level with respect to each indicator.

In India, the contribution made by women in their families is generally overlooked and daughters are perceived as an economic burden on the families owing to the expenditure which is incurred to raise them up and later on their marriages. Discrimination against the girl child in India is an existing reality which reflects the serious sex-based differences, inequalities and neglect (Shijith \& Sekher, 2015). 
Women are a discriminated lot, not only in every walk of life but before the onset of life itself. Table 1 depicts that except for Kerala and Puducherry, in all other States and U.Ts of India, the sex ratio is less than 1000. Comparing the Census reports of 2001 and 2011, though the sex ratio at all-India level has improved in Census report, 2011 (933 in 2001 and 943 in 2011), but the child sex ratio shows a declining trend for the same time period. Figures indicate the repercussions, that is, a skewed sex ratio will be there in the years to come if the trend remains unchanged. The child sex ratio has declined from 927 in 2001 to 919 as observed in 2011 Census report. Punjab, Sikkim, Jammu and Kashmir, Haryana, Andaman and Nicobar Islands, Delhi, Chandigarh, Dadra \& Nagar Haveli and Daman \& Diu fall in the category of those States and U.Ts where the sex ratio is lesser than even 900 . Dadra \& Nagar Haveli and Daman \& Diu have not performed well, as is evident from 2011 census report. The sex ratio in these two states is just 774 and 618 respectively.

Females are found to be the major victims of infanticide wherever such a practice takes place (George, Abel \& Miller, 2012). Moreover, malnourishment and morbidity is found to be more prevalent among females in India (Mehrotra, 2006). Over a period of time, crimes against women in India have also increased. One may realize that economic, social and cultural factors in combination have created a situation where a country is not able to mobilize exhaustive benefits from a vital segment of its human power. Women possess the much needed potential to accelerate the process of growth. In the words of former Secretary General of United Nations, Kofi Annan, "There is no tool for development more effective than the empowerment of women." The extent and dimension of the problem of marginalisation of women in India needs a thorough introspection by all stake holders if we want to reap the benefits of our demographic dividend. In the backdrop of this the present study has tried to make a socioeconomic analysis of the level of women participation in different spheres of life in India.

\section{Review of Literature:-}

The present study has been conducted with the prime motive of the analysis of female participation in different spheres of life in India. An attempt has been made to scan the literature available on the subject:

Mehrotra (2006) analysed the child malnutrition and gender discrimination in South Asia. The study focuses on India, Pakistan and Bangladesh, which accommodates half of the world's malnourished children. It has been revealed that South Asia is the worst performer on the front of malnutrition as per all the three indices i.e. underweight, stunting and wasting. Besides this, South Asia has the incidence of lowest birth weight and educational indicators in case of women as compared to any other region of the world. Sethuraman \& Duvvury (2007) explored the relationship between gender discrimination and malnutrition in South Asia. The collection of four papers presents findings on unmarried adolescent girls and newly married adolescent girls. Social acceptability of both temporary contraceptives and couple communication on contraception are found to be the key factors in creating an environment that enables couples to postpone their first pregnancy. Data indicate that couple communication is facilitated by the discussion of their aspirations for children and family planning at an early stage of marriage and its acceptance by the families and communities. Overall findings suggest that nutrition-gender nexus can only be addressed by an all-inclusive approach of meeting nutritional gaps through targeted intervention and by fostering empowerment among adolescent girls. Jose (2011) scrutinised the prevalence of gender discrimination in adult nutrition in India. The findings bring to light the coexistence of huge gender gap in iron deficiency along with the absence of gender gap in chronic energy deficiency (CED). The contrasting pattern indicates the complexity of gender gap in nutrition further reinforced by a wealth-based hierarchy in CED and gender based hierarchy in anaemia. Swaminathan, Lahoti \& Suchitra (2012) present the estimates of gender assets and wealth gaps in Karnataka. The results show substantial gender disparities with respect to asset ownership and wealth in Karnataka. There is strong evidence that the resources may not always be equitably distributed among household members. Gender inequality in asset ownership is found to be cutting across all economic classes. Mazumdar, Neetha \& Agnihotri (2013) present a sketch of the key findings of a research project on gender and migration. The macro-picture of the composition of male and female migrant workers indicates that the pattern of labour migration is aggravating gender biases in the labour market, particularly for industry and services. The mesolevel empirical findings postulate the need to look at migration, labor and labor laws in India by specifically examining how agrarian caste and patriarchy based social relations are being incorporated into migration based wage employment in more modern industries. Paul \& Raju (2014) evaluated the diversification of women's workspaces with time along with the process of economic restructuring. The study attempts to identify the industries in which women have been stereotypically clustered and finds out whether any change has come about therein. The analysis indicates that the labour market is consistently moving in favor of men in comparison to women. The progressive increase in the dissimilarity index indicates the rising gendered segregation of industries in the last 
twenty years, not only in terms of number of opportunities available but also in terms of nature of work done which is demonstrated by the education level of workers. Sengupta \& Das (2014) analysed gender wage discrimination across social and religious groups in India caused by social and economic factors. The study observes that the probability of women's participation rate in wage employment was lower as compared to that of men. Discrimination was found to be harsher for women workers from backward ethnic groups as compared to women belonging to other backgrounds. Sharma (2015) analysed gender inequality and gender-based crimes in India at the sub-national level. The findings reveal that gender-based crime rates have grown while the general crime-rates have declined over the years. The distribution of states by Gender Inequality Index (thereafter GII) doesn't follow a pattern. States with low and high GII show similar average rates for gender based crimes while moderate GII states show the highest average rates for gender based crimes. Shirith \& Sekher (2015) attempted a study on the families of Satara district of Maharashtra who named their daughters as Nakusa/ Nakoshi. The study illustrates how strongly the son's preference combined with traditional beliefs and sex segregated norms result in discrimination against girls. The practice is seen as an expression of gender discrimination existing in the society. The study advocates the need for socio-psychological and economic support for these girls.

The studies conducted previously have thus captured various aspects of gender discrimination as well as the exclusion of women. South Asia has the incidence of lowest birth weight and worst educational indicators for women as compared to any other region of the world. The relationship between malnutrition and gender in South Asia is found to be complex. The gender-based crime rates have grown in India overtime while in general, crime rates are found to be declining. The participation rate of women in wage employment is low as compared to that of men. The labour market seems to be acting in favour of men vis-à-vis women. The pattern of labour migration in India is aggravating gender biases in labour market particularly in case of industry and services. Gender disparities are found with respect to asset ownership and wealth. Huge gender gap exists in iron deficiency. The preference for a male child along with conventional values is resulting in discrimination against girl child in India.

Through the survey of literature available on the subject, we have come to know that various studies have tried to capture different aspects of participation level and gender discrimination in India but no rigorous attempt has been made to capture the participation level on gender basis, gender wise access to resources and the extent of quality of life enjoyed by women in a single study to understand the problem in a comprehensive manner. Present study is an attempt to fill this gap in literature by scrutinising the women's access to resources in India and to check the participation level of women in India in economic, political and social spheres in a single study to sketch a holistic view. The study will also try to explore the quality of life being enjoyed by women in India in relation to men.

\section{Objectives of the study:-}

Present study has been conducted with keeping in mind the following objectives:-

1. To evaluate women's access to resources in India

2. To sketch out the participation level of women in economic, political and educational spheres

3. To scan the quality of life of women in relation to men in India

\section{Analytical framework:-}

The present study is based on secondary data only. The various data sources used for the study are: Various Census reports of India, World Bank database, Millennium Development Goals indicator database, database of Inter Parliamentary Union (IPU), official websites of Ministry of Labour and Employment, Ministry of Human Resource Development and Ministry of Statistics and Programme Implementation, ILO Key Indicators of Labour Market database, Global database on Child Growth and Malnutrition, UN Inter-agency group for Child Mortality Estimation, NFHS-3, statistics of National Crime Records Bureau etc.

Discrimination, marginalisation and exclusion can be evaluated on certain parameters like resources, participation and quality of life. In order to evaluate women's access to resources in India; material as well as economic resources have been taken into consideration. In order to sketch the participation level of women; the pattern of women employment, educational attainment and political representation have been considered. To ascertain the quality of life of women in India; the health and well-being level of women vis-à-vis men and the extent of criminalisation against women during last few years have been examined.

Various objectives of the study are tried to be achieved using these secondary data already available in tabular form. Year-to-year growth fluctuations have been captured as: 
$\mathrm{G}_{\mathrm{t}}=\underline{\mathrm{Y}_{\mathrm{t}}} \underline{\underline{\mathrm{Y}}} \underline{\underline{\mathrm{t}-1}} \times 100$

$\mathrm{Y}_{\mathrm{t}-1}$

Here $G_{t}=$ Year-to-year growth rate

$Y_{t}=$ Value in the current year

$\mathrm{Y}_{\mathrm{t}-1}=$ Value in the last year

\section{Results and Discussion:-}

In order to achieve the above mentioned objectives, on the basis of examined data, results have been bought out to elucidate the women's access to resources in India, participation level of women in political, economic and educational spheres and quality of life being enjoyed by women in India.

The results and discussion for the study are as follows:-

\section{(1) Women's access to resources in India:-}

The measures of empowerment include an asset dimension by considering women's role in the purchase of assets or their ownership status (Garikipati, 2009). Access to resources can be treated as an indicator of the women empowerment. Asset ownership by women can have a positive impact on their status and bargaining power, thereby enhancing their individual and household well-being (Swaminathan et al., 2012). One of the indicators of asset ownership is account holding at a financial institution. Table 2 exhibits the percentage of men and women above 15 years of age holding accounts at a financial institution in India. It indicates that in the year 2011, only 26 per cent women had an account at a financial institution. Their share increased to about 43 per cent in the year 2014 but women's access remained lesser as compared to men as about 62 per cent men are holding accounts at a financial institution in India indicating a gender gap of 19 per cent.

The picture is approximately the same when we take into consideration the proportion of men and women holding credit and debit cards as observed in Table 3. The table exhibits that in the year 2011, 1.04 percent of women owned a credit card which increased marginally to 1.57 percent in the year 2014 . The corresponding figures for men in their own group for the same years were 2.48 per cent and 6.68 per cent respectively. The percentage of females holding debit card is better when compared to the former with 11.41 per cent of females holding a debit card in the year 2014. The figure for males in 2014 is 32.32 per cent, indicating a higher access to debit card by males as against females.

The statistics represent a disappointing state of affairs if we take into account other yardsticks as well, like decision making about the major household purchases and female headed households in India as depicted in Table 4. The table expresses the fact that the decisions about the major household purchases are taken either by husband alone or jointly by the husband and wife. In the households of 32.2 per cent married women, decision making about major household purchases is made by the husband and in 44.4 per cent of the households, the decision making about major household purchases is made jointly by the husband and wife. Only in 8.5 per cent households, the decision making about major household purchases is taken up by the wife. Decision making about major household purchases is made by others and someone else in 2.8 per cent and 12 per cent households respectively. Figures clearly exhibit the fact that women till date don't have at par 'Say' in their own families.

The percentage of female headed households in India have increased overtime but still their proportion remains far less as compared to men. Table 5 expresses the percentage of female headed households in India from 1993 to 2006. In the year 1993 there were 9.20 per cent female headed households in India which increased to 10.30 per cent in the year 1999. Up to the year 2006, 14.40 per cent of households were with a female head in India.

Resources are the elementary units women could draw on in order to succeed economically. At present women are far behind men in their access to various resources in India. A greater percentage of men hold debit and credit cards as compared to women. Decision-making about major household purchases is taken up mainly by the husband or jointly by the wife and husband. Only in 8.5 per cent of the households, the decision-making about major household purchases is made by the wife. The possibility of women headed households in India is no more than a pipedream. In the context of above scenario one can say that women are behind men with respect to their access to different resources in India. 


\section{Participation level of women in political, economic and educational spheres:-}

In India women for long were kept in 'purdah'. It was only in the beginning of $20^{\text {th }}$ century that their occurred some winds of change for women courtesy different reform movements. The involvement of women in day to day activities at micro as well as macro level signifies their enhanced participation level.

\subsection{Political participation:-}

The extent of political participation of women indicates their active role in the civic life of the country. Inadequate representation of women in decision making positions results in their agendas and issues not getting properly reflected in various government policies and programmes. Political empowerment of women may be regarded as a key driver of their economic and social empowerment. Little opportunity for women in political bodies has not only resulted in their meager presence in decision making bodies but also in neglect of their issues in policy making (www.iwraw-ap.org). The present section concentrates on the extent of political participation of women in India over time and relative examination of the situation in other countries as well.

Perusal of Table 6 brings out the level of political representation of women in the national parliament of India from the year 1990 to 2015. In the year 1990, women occupied only 5 per cent of the total seats in the national parliament of the country. Since 1990, the situation has improved slightly overtime and in the year 2015, females were occupying 12 per cent of the total seats in the national parliament. Till date the representation in national parliament of the country is highly skewed in favour of men.

Apart from this, women occupy a little share in the ministerial level positions in India. Table 7 shows the per cent share of women holding ministerial level positions in India ${ }^{1}$ during different years. In the year 2005, out of the total ministerial level positions in India, 3.4 per cent were held by the women. The figure kept on increasing till 2008 and started declining afterwards till 2014 when it reached to the level of 9.3 per cent. In the year 2015, 22.2 per cent of the total ministerial level positions were held by women, that is, the situation has improved up to some extent but still bias is clearly visible in favour of men.

The relative examination of the political representation of women in national parliaments of various countries has brought into notice that the top five positions are occupied by Rwanda, Bolivia, Cuba, Seychelles and Sweden respectively. With 12 per cent women in the national parliament, India occupies $104^{\text {th }}$ position out of a total of 194 nations as expressed in Table 8.

The exclusion of women from the positions of power affects the ability to challenge the subjugation of women. It is quite ironic to see that women who ideally constitute almost half of the population of every country are inadequately represented in the national parliaments of most of the countries. Women have to be in power and participate in politics to change the very nature of power which excludes them from it.

\subsection{Economic participation:-}

Employment of women is important as it ensures financial independence, a greater say in family matters and hence dignity in a society like India, which has witnessed women suppression for centuries. An increasing share of women in employment indicates a significant change in outlook towards them. Upsurge in level of women employment can be taken as an index of women empowerment. Present section of the paper brings out the participation of women in the economic life of the nation.

Perusal of Table 9a shows the growth of women employment in the total organised employment in India from 1980 to 2012. The rate of growth of women employment in India kept on fluctuating over the years. From 1980 to 2001, the growth rate of women employment has stayed positive. It was only in the years 2002 and 2004 that a negative growth rate was witnessed in women employment in comparison to other years. Beginning from 2.7 million in the year 1980, women employment has increased up to 6.05 million in the year 2012 .

The growth performance of women employment has been better than the overall growth performance of the total organised sector employment in India. Yet the growth performance has not been sufficient enough so as to bring about parity between men and women in the total organised employment in India. The statement is elaborated in Table $9 \mathrm{~b}$ which shows the share of women employment in total organised employment in India. During the last three decades, the share of women in total employment has increased from 12.1 percent in 1981 to 20.5 percent in 2012. 
The share of women in the total organised employment has definitely improved but till date they have not been able to occupy an equal share against men in the organised employment in the country.

The work participation rate of women is also lesser as compared to men as depicted in Table 10. From 1972-73 to 2011-12, the work participation rate in case of males has been more than that of females. The work participation rate of males, in both urban and rural areas has remained above 50 in the three decades (i.e. from 1972-73 to 201112). The work participation rate of females in rural and urban areas are 24.8 and 14.7 respectively in the year 201112. It is notable that the work participation rate of females in rural areas is more than that of their counterparts in urban areas.

On account of the modest participation of women in employment, they have not been able to occupy an equivalent share in important positions like legislators, senior officials and managers. Perusal of Table 11 brings out the percentage of female legislators, senior officials and managers of the total number of legislators, senior officials and managers. Fluctuations in the share occupied by women in this category are visible and figures are not good enough, showing a declining trend. In the year 1994, women occupied a share of 15.43 per cent in the total legislators, officials and mangers which declined to 13.95 per cent in 2000. The share again increased to 15.22 per cent in the year 2005 touching 13.75 per cent in the year 2010.

In comparison to men, lesser women are found to be employed as revealed by the discussion above. Even the ones who are employed face greater vulnerability in employment as compared to males. Table 12 specifies the vulnerability of employment among males and females in India. Starting from 1994 till 2010, the vulnerability of employment among females has remained high as compared to the males. Although among females vulnerability has declined from 91.09 per cent in 1994 to 85 per cent in 2010 but such high figures offer little solace. The vulnerability of employment among males has remained almost constant from 1994 to 2010, at 79 to 80 per cent, with minor fluctuations over the entire time period.

The analysis of the above tables clearly indicates that gender disparities exist in India in the sphere of economic participation. When women are economically empowered, communities and nations tread on the path of progress. Economic empowerment is one of the most powerful ways for women to achieve their potential and advance their rights. Hence the disparities in the level of economic participation ought to be reduced to achieve the broader development goals such as economic growth, poverty reduction, health, education and welfare.

\subsection{Educational Attainment:-}

Education is the process of facilitating learning, or the acquisition of knowledge, skills, values, beliefs, and habits (Dewey, 1963). Education is the most important instrument for human capital formation. Educating women is important for the development of a nation as it is said, "When you educate a girl, you educate a whole family." The issue of educating females is of such a paramount importance that it found a place for itself in the Millennium Development Goals (MDGs) set up by the United Nations. Educating girls is hence very crucial to improve the status of the girl child (Pandey, 2006).

The section brings out the level of educational attainment by females against males in India.

Table 13 traces the literacy rate of females as compared to males in India in the year 2011. At an aggregate level, the literacy rate in India in 2011 was 74.04 per cent. The literacy rate among males (82.14 per cent) in the same year was more than that of females (65.46 per cent). The overall picture shows that on an average, the literacy rate among males is greater as compared to females in all the States and Union Territories of India. Even in the most literate States and U.T.s such as Kerala, Lakshadweep and Mizoram the literacy rate among males is greater as compared to females, not to speak of states like Bihar, Arunachal Pradesh, Jharkhand, Rajasthan, Jammu and Kashmir and Uttar Pradesh, whose overall literacy rates is lesser as compared to the national average. The difference among literacy rate between males and females is more among the latter states and union territories as compared to the former.

Moreover if we go through the various census drafts, gender gap in literacy is clearly visible as exhibited in Table 14 which clearly shows that in 1951, the gender gap in the literacy rate was about 18 per cent. It increased initially in the first decade after independence and touched the level of 25 per cent in the year 1961. Partially this increase can be attributed to the high growth rate of population in India after independence. Thereafter in the 1971, it declined marginally and again escalated to the level of 26.6 per cent in the census of 1981. After 1981, the gender gap in the literacy has observed a steady decline and was found at the level of 16.68 per cent in the 2011 . Although, the male- 
female gap in the literacy rate has declined but it is desirable that gap must reduce further, so as to attain equanimity in education with respect to women in the society. The difference in the educational attainment between men and women can be measured by taking into consideration Gross Enrolment Ratio $(G E R)^{2}$ and Gender Parity Index $(G P I)^{3}$.

Table 15 presents GER for students at the primary and upper-primary level from 1950-51 to 2013-14. Combining the data at the primary and upper primary level, we can get the overall status of the elementary level of education. In the year 1950-51, the overall GER was 32.1, GER for boys being 46.4 and for girls being 17.7. An amazing progress was achieved afterwards, for boys and girls, at both primary and upper primary level of education. In the year 200607, the GER for boys at the elementary level of education was 100.4. The figure 100 for females was achieved a few years later in 2009-10. A slight decline was visible in GER afterwards.

GER at secondary, senior secondary and higher levels of education is presented in Table 16. In the year 2004-05, at secondary level of education, the GER for males was 57.4 and for females was 45.3. The GER at secondary level has grown persistently and the male-female gap has declined overtime. In the year 2013-14, the overall GER was 73.6 out of which the GER for males was 73.5 and for females was 73.7. At the senior secondary level of education, the overall GER in the year 2004-05 was 27.8; GER for boys being 30.8 and for girls being 24.5. GER at the senior secondary level improved afterwards along with a decline in the gender gap. Parity in GER at this level of education was achieved in the year 2013-14.

At higher level of education, the GER has remained low throughout. In the year 2001-02, the overall GER was 8.1. The GER for boys in the same year was 9.3 and for girls was 6.7. Over a decade, the GER for boys increased by more than two times and for girls increased by more than three times in the year 2012-13 in comparison to the figures in 2001-02.

Today at the secondary and senior secondary level of education, the gender gap in the GER has almost eradicated and at the higher level, the gender gap is to the tune of just 3 percentage points but the GER at these levels is lesser as compared to the GER at elementary level of education.

Combining the data from Table 15 and Table 16 one can infer that over a period of time, the GER at all levels of education has improved and the gender gap has also declined but more progress can be seen at the elementary level of education as compared to the secondary, senior secondary and higher levels.

One more way of capturing the prejudices against women in educational attainment is by the calculation of GPI which is presented in Table 17. The table shows GPI at different levels of education in India from 1950-51 to 201314. At the primary level of education in the year 1950-51, GPI was 0.41 and for the first three decades after independence, GPI was 0.67. GPI of 1 at primary level was achieved in the year 2009-10 and after that GPI has become more than 1 . At the time of independence, at the upper-primary level GPI was 0.22 and in the year 2012-13, GPI was 1.05. A GPI of 1 at the secondary and senior secondary level was achieved in 2013-14. GPI at higher level of education was 0.89 in the year 2012-13.

The above section brings out the educational attainment by females vis-à-vis males in India. Starting from 18.3 per cent in 1951 the gender gap in literacy fluctuated over the years, reaching to 16.6 per cent in the year 2011. Even in the most literate states and U.T.s of India the literacy rate among females was found to be lesser as compared to males. The picture of gender parity at different levels of education shows that though at the elementary, secondary and senior secondary level of education, parity between males and females has been achieved at present but it took almost more than six decades to reach to get to that place. At higher level of education, gender parity still remains a far-flung goal owing to the precedence given to males over females.

\section{Quality of life and well-being:-}

This section brings out the quality of life and well-being enjoyed by women in India. The various indicators used in the present section are the prevalence of mortality rate and over-weight among children (males and females) less than 5 years of age and crimes committed against women in India. A gender-wise break up is also seen with respect to age at the time of marriage, sterilisation, nutritional status, prevalence of anaemia and the knowledge of HIV/AIDS. 
Table 18 brings out the mortality rates below five years of age among males and females in India. From 1990 to 2015, the mortality rate among females has remained higher as compared to males in India. The overall mortality rate in the year 1990 was 125.8 per 1000 children which has declined continuously thereafter reaching to 47.7 in the year 2015. The mortality rate among females has remained more as compared to males from 1990 to 2015 . In the year 1990, the mortality rate among males was 121.8 . The female mortality rate during the same year was 130 . An unrelenting decline in both the male and female mortality rate was visible afterwards. The male mortality rate declined to 86.6 in 2000, to 57 in the year 2010 and was 46.3 in the year 2015. In the same years the female mortality rate was $96.1,62.9$ and 49.2 respectively. Although the decline has been colossal in the last two and a half decades but till date the female mortality rate is more as compared to the male mortality rate.

While the indicators of scarcity are peculiar to females, the indicators of plenty are representative of males as shown by the statistics. Table 19 shows the prevalence of over-weight among males and females in India. The analysis shows that over-weight is found to be more among males as compared to females in India. In the year 1992, 3.09 per cent of females were over-weight which declined to 1.7 per cent in the year 2006. He corresponding figures for males in the same time period were 3.2 per cent and 2.2 per cent respectively.

From the perspective of human development, mortality rates demand greater priority as compared to obesity as it signifies deprivation or deficiency of basic facilities, than obesity, which indicates excess (Jose, 2011).

Many more indicators of health and well-being are covered by the National Family Health Survey (NFHS). Table 20 brings out the results of NFHS-3 in India. It can be seen from the table that 47.4 per cent of women in the age group 20-24 years are married by the age of 18 years in comparison to 32.3 per cent of men in the age group of 25-29 years who are married by the age of 21 years. Sterilisation in order to control child birth is resorted to mainly by women both in rural and urban areas. Combining the data for both the areas, one can see that 37.3 per cent of women are sterilised in comparison to 1 percent men.

The Body Mass Index (BMI) for women is lower as compared to men and anaemia is also found to be more prevalent among females. A lesser percentage of women have heard of AIDS and the benefits of condom usage in reducing the chances of HIV/AIDS in comparison to men. Even among women, rural women are less aware in comparison to their urban counterparts.

An important yardstick to gauge the extent of well-being enjoyed by women is to take into consideration the magnitude of crimes committed against them. Perusal of Table 21 presents a longitudinal picture of various crimes committed against women in India from 2001 to 2012. The absolute number of crimes committed against women has registered an overall increase from 143795 in 2001 to 244270 in the year 2012. Coming to various crime heads one can notice that there has been an increase in the number of rapes, kidnapping and abduction of women and girls, dowry deaths, assaults on women with intent to outrage her modesty, cruelties by husband or relatives and the cases registered under Dowry Prohibition Act. Crimes conducted with the intent to insult the modesty of women have more or less remained the same with minor fluctuations over the years from 2001 to 2012. The importation of girls from the foreign country has halved over the years. The cases registered under Immoral Traffic (P) Act has declined by about 71 percentage points and the cases registered under Indecent Representation of Women (P) Act has declined by 87 percentage points from 2001 to 2012. The cases registered under Commission of Sati (P) Act have more or less remained zero over the entire time-period.

The section brings out the overall quality of life enjoyed by women in India. The mortality rates are more among females as compared to males and obesity among children is found to be prevalent more among the male children. A high percentage of women are married off by the age of 18 years. Sterilisation practices are mainly adopted by women. Only a miniscule portion of men go for sterilisation in both urban and rural areas. The BMI among females is found to be lower in comparison to males and anaemia is also acutely found to be prevalent among females. The dangers of HIV/AIDS and the knowledge of contraceptives is still lacking among females in India. On an average the crimes against women in India have increased.

\section{Findings and Conclusions:-}

The study has been conducted keeping in mind the objective of evaluation of women's access to resources in India, assessment of participation level of women in economic, political and educational spheres and to make an appraisal 
of the quality of life of women in relation to men in India. For the present study the data were taken up from a number of sources. Various findings and observations of the study are as follows:-

Evaluating the access to resources by women in India it was observed that as compared to men lesser women were holding accounts at financial institutions, credit cards and debit cards. Low access to resources indicates the reservations faced by women while making day-to-day purchases. Moreover, the decision making about major household purchases in India was made either by the husband or jointly by the wife and husband. Only 12 percent women were found to be taking decisions about the major household purchases again expressing the little autonomy exercised by women. Females occupy a diminutive share in heading households in India indicating the traditional patriarchal mindset of the Indian society. Though one can see some winds of change occurring within the traditional mindsets of the people, it would take time before the effects become glaring.

An enquiry into political participation of women in India revealed that even at present women's share in national parliament of India is negligible as compared to men. If we see the proportion of women holding ministerial level positions in India the story is much the same. India stands at $104^{\text {th }}$ position out of a total of 194 nations in the political representation of women in the national parliament. Women have to be at the helm of affairs of national importance and have to participate in the activities of the nation in order to negotiate the matters which are of consequence for their own empowerment.

In the sphere of economic participation it was revealed that till date women have not been able to occupy an equal share against men in the organised employment in India. The work participation rate of men is more both in rural and urban areas. Vulnerability in employment more among them as compared to males in India and they occupy a meager share in the total number of legislators, senior officials and managers in India. Employment gives financial autonomy to a woman which makes her the master of her own life but the gloomy figures is only indicative of a situation in which women have to be asking for finances from males in their families, a complete annihilation to their financial independence.

The gender breakdown of educational sector in India exhibits a poorer literacy rate among females as compared to males and the plight is same in all the states and U.T.s of India. The literacy rate among females is lesser as compared to males even in the most literate states/ U.T.s of India like Kerala, Lakshadweep and Mizoram. The gender gap in literacy in India stood at 16.68 percent in the year 2011. The picture of gender parity across different levels of education shows that although at the elementary, secondary and senior secondary level of education parity between males and females has been achieved at present but it took more than sixty years to attain such parity. At higher level of education, achieving gender parity still remains an uphill battle as more preference is being given to males as compared to females. Educating women is critical to the put a nation on the trajectory of growth as women possess the much needed potential for the development of a nation. A country which doesn't treat its women at par with men will always lag behind in the process of development. In the words of 2014 Nobel Peace prize winner, Malala Yousafzai, "We cannot all succeed if half of us are held back".

The scrutiny of quality of life and well-being enjoyed by women in India brings out higher mortality rates among females as compared to males below five years of age and the prevalence of overweight more among males as compared to females. A lower BMI, prevalence of anaemia, little knowledge about HIV/AIDS and contraceptives and a high degree of sterilisation is what characterizes Indian women at the health front. The poor indicators are representative of the status of women in India. Crimes against women in India have witnessed an upsurge in the past decade with rapes, kidnapping and abduction of women and girls, dowry deaths, assaults on women and cruelties by husband becoming the talk of the town.

The study brings out the reality of the levels of female participation in various walks of life in India. Over a period of time, the situation has improved for women. Today women have a better access to various resources and they are participating more in political, economic and educational spheres of life. The health status of women has also improved but a comparison of all these indicators with those of men brings out the fact that women are still lagging behind men almost in all the indicators which formed the subject-matter of our study.

A thorough appraisal of the causes behind their lower status in comparison to men is the need of the hour. A change in the mindset and attitude of people for women would go a long way in raising their status at par with men in all spheres of life. 
Table 1:- Sex Ratio in India

\begin{tabular}{|c|c|c|c|c|c|c|c|}
\hline \multirow{2}{*}{$\begin{array}{l}\text { Sr. } \\
\text { No. }\end{array}$} & \multirow[t]{2}{*}{ States/ U.T.'s } & \multicolumn{2}{|c|}{2011 Census } & \multicolumn{2}{|c|}{2001 Census } & \multicolumn{2}{|c|}{ Gender Gap } \\
\hline & & $\begin{array}{c}\text { Sex } \\
\text { Ratio }\end{array}$ & $\begin{array}{c}\text { Child Sex } \\
\text { Ratio }\end{array}$ & $\begin{array}{c}\text { Sex } \\
\text { Ratio }\end{array}$ & $\begin{array}{c}\text { Child Sex } \\
\text { Ratio }\end{array}$ & $\begin{array}{c}2011 \\
\text { Census }\end{array}$ & $\begin{array}{c}2001 \\
\text { Census }\end{array}$ \\
\hline 1 & Kerala & 1084 & 964 & 1058 & 960 & 84 & 58 \\
\hline 2 & Puducherry & 1037 & 967 & 1001 & 967 & 37 & 1 \\
\hline 3 & Tamil Nadu & 996 & 943 & 987 & 942 & -4 & -13 \\
\hline 4 & Andhra Pradesh & 993 & 939 & 978 & 961 & -7 & -22 \\
\hline 5 & Chhattisgarh & 991 & 969 & 989 & 975 & -9 & -11 \\
\hline 6 & Meghalaya & 989 & 970 & 972 & 973 & -11 & -28 \\
\hline 7 & Manipur & 985 & 930 & 974 & 957 & -15 & -26 \\
\hline 8 & Orissa & 979 & 941 & 972 & 953 & -21 & -28 \\
\hline 9 & Mizoram & 976 & 970 & 935 & 964 & -24 & -65 \\
\hline 10 & Karnataka & 973 & 948 & 965 & 946 & -27 & -35 \\
\hline 11 & Goa & 973 & 942 & 961 & 938 & -27 & -39 \\
\hline 12 & Himachal Pradesh & 972 & 909 & 968 & 896 & -28 & -32 \\
\hline 13 & Uttarakhand & 963 & 890 & 962 & 908 & -37 & -38 \\
\hline 14 & Tripura & 960 & 957 & 948 & 966 & -40 & -52 \\
\hline 15 & Assam & 958 & 962 & 935 & 965 & -42 & -65 \\
\hline 16 & West Bengal & 950 & 956 & 934 & 960 & -50 & -66 \\
\hline 17 & Jharkhand & 948 & 948 & 941 & 965 & -52 & -59 \\
\hline 18 & Lakshadweep & 946 & 911 & 948 & 959 & -54 & -52 \\
\hline 19 & Arunachal Pradesh & 938 & 972 & 893 & 964 & -62 & -107 \\
\hline 20 & Nagaland & 931 & 943 & 900 & 964 & -69 & -100 \\
\hline 21 & Madhya Pradesh & 931 & 918 & 919 & 932 & -69 & -81 \\
\hline 22 & Maharashtra & 929 & 894 & 922 & 913 & -71 & -78 \\
\hline 23 & Rajasthan & 928 & 888 & 921 & 909 & -72 & -79 \\
\hline 24 & Gujarat & 919 & 890 & 920 & 883 & -81 & -80 \\
\hline 25 & Bihar & 918 & 935 & 919 & 942 & -82 & -81 \\
\hline 26 & Uttar Pradesh & 912 & 902 & 898 & 916 & -88 & -102 \\
\hline 27 & Punjab & 895 & 846 & 876 & 798 & -105 & -124 \\
\hline 28 & Sikkim & 890 & 957 & 875 & 963 & -110 & -125 \\
\hline 29 & Jammu and Kashmir & 889 & 862 & 892 & 941 & -111 & -108 \\
\hline 30 & Haryana & 879 & 834 & 861 & 819 & -121 & -139 \\
\hline 31 & $\begin{array}{l}\text { Andaman and Nicobar } \\
\text { Islands }\end{array}$ & 876 & 968 & 846 & 957 & -124 & -154 \\
\hline 32 & Delhi & 868 & 871 & 821 & 868 & -132 & -179 \\
\hline 33 & Chandigarh & 818 & 880 & 777 & 845 & -182 & -223 \\
\hline 34 & Dadra and Nagar Haveli & 774 & 926 & 812 & 979 & -226 & -188 \\
\hline \multirow[t]{2}{*}{35} & Daman and Diu & 618 & 904 & 710 & 926 & -382 & -290 \\
\hline & India (Aggregate) & 943 & 919 & 933 & 927 & & \\
\hline \multicolumn{8}{|c|}{ SOURCE: Census Draft of $2001,2011}$. \\
\hline \multicolumn{8}{|c|}{ NOTE: 1. (-) figures indicate less females as compared to males. } \\
\hline \multicolumn{8}{|c|}{ 2. (+) figures indicate more females as compared to males. } \\
\hline \multicolumn{8}{|c|}{ 3. Sex Ratio: Number of females per thousand males. } \\
\hline & 4. Child Sex Ratio: The & mber of & ales per thou & $\mathrm{dmale}$ & age grc & & \\
\hline
\end{tabular}

Table 2:- Accounts at a financial institution in India

\begin{tabular}{|c|c|c|c|}
\hline Year & Female (age 15+) & Male (age 15+) & \\
\hline 2011 & $26 \%$ & $43 \%$ & $62 \%$ \\
\hline 2014 & $43 \%$ & $62 \%$ & \\
\hline \multicolumn{2}{|l|}{ SOURCE: Demirguc-Kunt et al. 2015, World Bank Database, 2016. } \\
\hline
\end{tabular}


Table 3:- Men and women holding credit and debit cards in India

\begin{tabular}{|c|c|c|c|c|}
\hline Year & $\begin{array}{c}\text { Credit card, } \\
\text { female (age 15+) }\end{array}$ & $\begin{array}{c}\text { Credit card, male } \\
(\text { age 15+) }\end{array}$ & $\begin{array}{c}\text { Debit card, female (age } \\
\mathbf{1 5 +}\end{array}$ & $\begin{array}{c}\text { Debit card, male (age } \\
\mathbf{1 5 +}\end{array}$ \\
\hline 2011 & $1.04 \%$ & $2.48 \%$ & $4.58 \%$ & $12.12 \%$ \\
\hline 2014 & $1.57 \%$ & $6.68 \%$ & $11.41 \%$ & $32.32 \%$ \\
\hline
\end{tabular}

Table 4:- Decision Making about major household purchases in India (2006)

\begin{tabular}{|c|c|c|}
\hline Sr. No. & Indicator & Amongst married women aged 15-49 years \\
\hline 1 & Decision about Major household purchases: mainly \\
husband & $32.2 \%$ \\
\hline 2 & Decision mabout Major household purchases: mainly wife & $8.5 \%$ \\
\hline 3 & Decision about Major household purchases: other & $2.8 \%$ \\
\hline 4 & Decision about Major household purchases: someone else & $12 \%$ \\
\hline 5 & $\begin{array}{c}\text { Decision about Major household purchases: wife and } \\
\text { husband jointly }\end{array}$ & $44.4 \%$ \\
\hline \multicolumn{2}{|c|}{ SOURCE: Demographic and Health Surveys (DHS) in India as quoted in World Bank Indicators, 2016.} \\
\hline
\end{tabular}

Table 5:- Female Headed Households in India

\begin{tabular}{|c|c|}
\hline Year & Percentage of Aggregate Households \\
\hline 1993 & $9.20 \%$ \\
\hline 1999 & $10.30 \%$ \\
\hline 2006 & $14.40 \%$ \\
\hline
\end{tabular}

SOURCE: Demographic and Health Surveys India, World Bank Indicators, 2016.

Table 6:- Political Representation of women in national parliament of India

\begin{tabular}{|c|c|c|c|}
\hline Year & Total Number of Seats & Seats Held by Men & $\begin{array}{c}\text { Seats Held by } \\
\text { Women }\end{array}$ \\
\hline 1990 & $521(100)$ & $495(95)$ & $26(5)$ \\
\hline 1997 & $545(100)$ & $506(92.8)$ & $39(7.2)$ \\
\hline 1998 & $545(100)$ & $506(92.8)$ & $39(7.2)$ \\
\hline 1999 & $543(100)$ & $499(91.9)$ & $44(8.1)$ \\
\hline 2000 & $543(100)$ & $494(91)$ & $49(9)$ \\
\hline 2001 & $544(100)$ & $495(91)$ & $49(9)$ \\
\hline 2002 & $543(100)$ & $495(91.2)$ & $48(8.8)$ \\
\hline 2003 & $543(100)$ & $495(91.2)$ & $48(8.8)$ \\
\hline 2004 & $543(100)$ & $495(91.2)$ & $48(8.8)$ \\
\hline 2005 & $543(100)$ & $498(91.7)$ & $45(8.3)$ \\
\hline 2006 & $545(100)$ & $500(91.7)$ & $45(8.3)$ \\
\hline 2007 & $545(100)$ & $500(91.7)$ & $49(9.1)$ \\
\hline 2008 & $541(100)$ & $492(90.9)$ & $49(9.1)$ \\
\hline 2009 & $541(100)$ & $492(90.9)$ & $59(10.8)$ \\
\hline 2010 & $545(100)$ & $486(89.2)$ & $59(10.8)$ \\
\hline 2011 & $545(100)$ & $486(89.2)$ & $60(11)$ \\
\hline 2012 & $545(100)$ & $485(89)$ & $60(11)$ \\
\hline 2013 & $545(100)$ & $485(89)$ & $62(11.4)$ \\
\hline 2014 & $545(100)$ & $483(88.6)$ & $65(12)$ \\
\hline 2015 & $543(100)$ & $478(88)$ & \\
\hline
\end{tabular}

SOURCE: Millenium Development Goals indicators database.

NOTE: Figures in parentheses represent percentages. 
Table 7:- Women holding ministerial level positions in India

\begin{tabular}{|c|c|}
\hline Year & Women holding ministerial positions (as a percentage of the total ministerial positions) \\
\hline 2005 & $3.40 \%$ \\
\hline 2008 & $10.30 \%$ \\
\hline 2010 & $10 \%$ \\
\hline 2012 & $9.80 \%$ \\
\hline 2014 & $9.30 \%$ \\
\hline 2015 & $22.20 \%$ \\
\hline \multicolumn{2}{|l}{} \\
\hline
\end{tabular}

Table 8:- Political Representation of women in national parliament of various countries

\begin{tabular}{|c|c|c|c|c|c|}
\hline \multirow[t]{2}{*}{ Rank } & \multirow[t]{2}{*}{ Country } & \multicolumn{4}{|c|}{ Lower or Single House } \\
\hline & & Elections & $\begin{array}{l}\text { Total } \\
\text { Seats }\end{array}$ & Women & $\begin{array}{c}\text { Percent Share of } \\
\text { Women }\end{array}$ \\
\hline 1 & Rwanda & Sep. 2013 & 80 & 51 & $63.80 \%$ \\
\hline 2 & Bolivia & Oct. 2014 & 130 & 69 & $53.10 \%$ \\
\hline 3 & Cuba & Feb. 2013 & 612 & 299 & $48.90 \%$ \\
\hline 4 & Seychelles & Sep. 2011 & 32 & 14 & $43.80 \%$ \\
\hline 5 & Sweden & Sep. 2014 & 349 & 152 & $43.60 \%$ \\
\hline 8 & South Africa ${ }^{@}$ & May-14 & 400 & 168 & $42.00 \%$ \\
\hline 13 & Norway & Sep. 2013 & 169 & 67 & $39.60 \%$ \\
\hline 17 & Denmark & Jun. 2015 & 179 & 67 & $37.40 \%$ \\
\hline 18 & Netherlands & Sep. 2012 & 150 & 56 & $37.30 \%$ \\
\hline 21 & Germany & Sep. 2013 & 631 & 230 & $36.50 \%$ \\
\hline 29 & Switzerland & Oct. 2015 & 200 & 64 & $32.00 \%$ \\
\hline 35 & Italy & Feb. 2013 & 630 & 195 & $31.00 \%$ \\
\hline 39 & Nepal & Nov. 2013 & 599 & 177 & $29.50 \%$ \\
\hline 40 & United Kingdom & May-15 & 650 & 191 & $29.40 \%$ \\
\hline 41 & Luxembourg & Oct. 2013 & 60 & 17 & $28.30 \%$ \\
\hline 42 & Afghanistan & Sep. 2010 & 249 & 69 & $27.70 \%$ \\
\hline 46 & Australia & Sep. 2013 & 150 & 40 & $26.70 \%$ \\
\hline 48 & France & Jun. 2012 & 577 & 151 & $26.20 \%$ \\
\hline 49 & Canada & Oct. 2015 & 338 & 88 & $26.00 \%$ \\
\hline 56 & Singapore & Sep. 2015 & 92 & 22 & $23.90 \%$ \\
\hline 58 & China & Mar. 2013 & 2959 & 699 & $23.60 \%$ \\
\hline 68 & Pakistan & May-13 & 340 & 70 & $20.60 \%$ \\
\hline 72 & Bangladesh & Jan. 2014 & 350 & 70 & $20.00 \%$ \\
\hline 75 & $\begin{array}{l}\text { United States of } \\
\text { America }\end{array}$ & Nov. 2014 & 434 & 84 & $19.40 \%$ \\
\hline 109 & India & Apr. 2014 & 543 & 65 & $12.00 \%$ \\
\hline 126 & Bhutan & Jul. 2013 & 47 & 4 & $8.50 \%$ \\
\hline 133 & Maldives & Mar. 2014 & 85 & 5 & $5.90 \%$ \\
\hline 136 & Sri Lanka & Aug. 2015 & 225 & 11 & $4.90 \%$ \\
\hline 142 & Kuwait & Jul. 2013 & 65 & 1 & $1.50 \%$ \\
\hline 144 & Qatar & Jul. 2013 & 35 & 0 & $0.00 \%$ \\
\hline
\end{tabular}

SOURCE: Database of Inter Parliamentary Union (IPU).

NOTE: @ : The figures on the distribution of seats in the national parliament of South Africa do not include the 36 special rotating delegates appointed on an ad-hoc basis, and all percentages given are therefore calculated on the basis of 54 permanent seats. 
Table 9a:- Growth of women employment in India

\begin{tabular}{|c|c|c|}
\hline Year (March End) & Total Employment (In Millions) & Women Employment (In Millions) \\
\hline 1980 & 22.31 & 2.70 \\
\hline 1981 & $22.88(2.55)$ & $2.79(3.41)$ \\
\hline 1982 & $23.49(2.67)$ & $2.89(3.51)$ \\
\hline 1983 & $24.01(2.21)$ & $3.00(3.87)$ \\
\hline 1984 & $24.21(0.83)$ & $3.05(1.63)$ \\
\hline 1985 & $24.58(1.53)$ & $3.17(3.97)$ \\
\hline 1986 & $25.06(1.95)$ & $3.26(2.74)$ \\
\hline 1987 & $25.39(1.32)$ & $3.35(2.85)$ \\
\hline 1988 & $25.71(1.26)$ & $3.44(2.81)$ \\
\hline 1989 & $25.96(0.97)$ & $3.56(3.22)$ \\
\hline $1990^{*}$ & $26.35(1.5)$ & $3.63(2.17)$ \\
\hline 1991* & $26.73(1.44)$ & $3.77(3.72)$ \\
\hline $1992 *$ & $27.05(1.22)$ & $3.89(3.21)$ \\
\hline 1993 & $27.18(0.45)$ & $4.03(3.52)$ \\
\hline 1994 & $27.37(0.73)$ & $4.15(3.15)$ \\
\hline 1995 & $27.52(0.55)$ & $4.23(1.8)$ \\
\hline 1996 & $27.94(1.52)$ & $4.43(4.68)$ \\
\hline 1997 & $28.24(1.08)$ & $4.64(4.77)$ \\
\hline 1998 & $28.16(-0.28)$ & $4.77(2.93)$ \\
\hline 1999 & $28.11(-0.18)$ & $4.83(1.17)$ \\
\hline 2000 & $27.96(-0.55)$ & $4.92(1.93)$ \\
\hline 2001 & $27.72(-0.86)$ & $4.95(0.63)$ \\
\hline 2002 & $27.19(-1.9)$ & $4.94(-0.32)$ \\
\hline 2003 & $27.00(-0.71)$ & $4.97(0.63)$ \\
\hline 2004 & $26.44(-2.06)$ & $4.93(-0.69)$ \\
\hline 2005 & $26.46(0.05)$ & $5.02(1.66)$ \\
\hline 2006 & $26.99(2.02)$ & $5.12(2.09)$ \\
\hline 2007 & $27.28(1.05)$ & $5.31(3.73)$ \\
\hline 2008 & $27.55(0.99)$ & $5.51(3.77)$ \\
\hline 2009 & $28.10(1.99)$ & $5.58(1.23)$ \\
\hline 2010 & $28.71(2.17)$ & $5.86(5)$ \\
\hline 2011 & $29.00(1.01)$ & $5.95(1.62)$ \\
\hline 2012 & $29.58(2)$ & $6.05(1.68)$ \\
\hline
\end{tabular}

SOURCE: Employment Review, Ministry of Labour and Employment, Government of India, Various issues.

NOTE: 1. Figures in parentheses represent year-to-year growth rates.

*Data as per Quarterly Employment Review.

Table 9b:- Share Of Women in total organised employment in India

\begin{tabular}{|c|c|c|c|}
\hline Year (March End) & $\begin{array}{c}\text { Women Employment (In } \\
\text { Millions) }\end{array}$ & Total Employment (In Millions) & $\begin{array}{c}\text { Percent share of } \\
\text { women }\end{array}$ \\
\hline 1980 & 2.70 & 22.31 & 12.1 \\
\hline 1981 & 2.79 & 22.88 & 12.2 \\
\hline 1982 & 2.89 & 23.49 & 12.3 \\
\hline 1983 & 3.00 & 24.01 & 12.5 \\
\hline 1984 & 3.05 & 24.21 & 12.6 \\
\hline 1985 & 3.17 & 24.58 & 12.9 \\
\hline 1986 & 3.26 & 25.06 & 13 \\
\hline 1987 & 3.35 & 25.39 & 13.2 \\
\hline 1988 & 3.44 & 25.71 & 13.7 \\
\hline 1989 & 3.56 & 25.96 & 13.8 \\
\hline $1990^{(}$ & 3.63 & 26.35 & 14.1 \\
\hline $1991^{\Theta}$ & 3.77 & 26.73 & \\
\hline
\end{tabular}




\begin{tabular}{|c|c|c|c|}
\hline $1992^{\Theta}$ & 3.89 & 27.05 & 14.4 \\
\hline 1993 & 4.03 & 27.18 & 14.8 \\
\hline 1994 & 4.15 & 27.37 & 15.2 \\
\hline 1995 & 4.23 & 27.52 & 15.4 \\
\hline 1996 & 4.43 & 27.94 & 15.8 \\
\hline 1997 & 4.64 & 28.24 & 16.4 \\
\hline 1998 & 4.77 & 28.16 & 17.2 \\
\hline 1999 & 4.83 & 28.11 & 17.6 \\
\hline 2000 & 4.92 & 27.96 & 17.9 \\
\hline 2001 & 4.95 & 27.72 & 18.4 \\
\hline 2002 & 4.94 & 27.19 & 18.7 \\
\hline 2003 & 4.97 & 27.00 & 19 \\
\hline 2004 & 4.93 & 26.44 & 19 \\
\hline 2005 & 5.02 & 26.46 & 19.5 \\
\hline 2006 & 5.12 & 26.99 & 20 \\
\hline 2007 & 5.31 & 27.28 & 19.9 \\
\hline 2008 & 5.51 & 27.55 & 20.4 \\
\hline 2009 & 5.58 & 28.10 & 20.5 \\
\hline 2010 & 5.86 & 28.71 & 20.5 \\
\hline 2011 & 5.95 & 29.00 & \\
\hline 2012 & 6.05 & 29.58 & \\
\hline
\end{tabular}

SOURCE: Employment Review, Ministry of Labour and Employment, Government of India, Various issues.

NOTE: @ Data as per Quarterly Employment Review.

Table 10:- Area-wise women's work participation rate in India

\begin{tabular}{|c|c|c|c|c|}
\hline \multirow{2}{*}{ Year } & \multicolumn{2}{|c|}{ Rural } & \multicolumn{2}{c|}{ Urban } \\
\cline { 2 - 5 } & Female & Male & 13.4 & 50.1 \\
\hline $1972-73$ & 31.8 & 54.5 & 15.6 & 50.8 \\
\hline $1977-78$ & 33.1 & 55.2 & 15.1 & 51.2 \\
\hline $1983-84$ & 34 & 54.7 & 15.2 & 50.6 \\
\hline $1987-88$ & 32.3 & 53.9 & 15.5 & 52.1 \\
\hline $1993-94$ & 32.8 & 55.3 & 13.6 & 51.9 \\
\hline $1994-95$ & 31.7 & 56 & 13.1 & 52.5 \\
\hline $1995-96$ & 29.5 & 55.1 & 11.4 & 52.1 \\
\hline $1996-97$ & 29.1 & 55 & 13.9 & 50.9 \\
\hline 1998 & 26.3 & 53.9 & 14 & 51.8 \\
\hline $1999-00$ & 29.9 & 53.1 & 13.9 & 53.1 \\
\hline $2000-01$ & 28.7 & 54.4 & 14 & 55.3 \\
\hline $2001-02$ & 31.4 & 54.6 & 16.6 & 53.4 \\
\hline 2002 & 28.1 & 54.6 & 14.3 & 54.9 \\
\hline $2004-05$ & 32.7 & 54.6 & 13.8 & 54 \\
\hline $2005-06$ & 31 & 54.9 & 13.8 & 55.4 \\
\hline $2007-08$ & 28.9 & 54.8 & 14.7 & 54.3 \\
\hline $2009-10$ & 26.1 & 54.7 & 54.3 & 54.6 \\
\hline
\end{tabular}

SOURCE: Ministry of Statistics and Programme Implementation, Government of India.

NOTE: Figures for all the years are based on Usual Status Approach and include Principal status and Subsidiary status workers of all ages.

Table 11:- Female Legislators, Senior Officials and Managers in India

\begin{tabular}{|c|c|}
\hline Year & Female Legislators, Senior Officials and Managers in India (as a percentage of the total) \\
\hline 1994 & $15.43 \%$ \\
\hline 2000 & $13.95 \%$ \\
\hline 2005 & $15.22 \%$ \\
\hline 2010 & $13.75 \%$ \\
\hline SOURCE: ILO Key Indicators of the Labour Market (KILM). \\
\hline
\end{tabular}


Table 12:- Vulnerabitity of Employment

\begin{tabular}{|l|l|l|l|}
\hline Year & $\begin{array}{l}\text { Vulnerable employment, } \\
\text { female as percentage of total } \\
\text { female employment }\end{array}$ & $\begin{array}{l}\text { Vulnerable employment, male } \\
\text { as percentage of total male } \\
\text { employment }\end{array}$ & $\begin{array}{l}\text { Vulnerable employment, as } \\
\text { percentage of total } \\
\text { employment }\end{array}$ \\
\hline 1994 & $91.09 \%$ & $79.8 \%$ & $83.09 \%$ \\
\hline 2000 & $90.4 \%$ & $80.5 \%$ & $83.4 \%$ \\
\hline 2005 & $89.59 \%$ & $80.3 \%$ & $83.09 \%$ \\
\hline 2010 & $85 \%$ & $79.3 \%$ & $80.8 \%$ \\
\hline
\end{tabular}

SOURCE: Key indicators of Labour Market Database, ILO.

Table 13:- Literacy rate in India (Census 2011)

\begin{tabular}{|c|c|c|c|c|}
\hline Sr. No. & States/ U.T.s & Overall Literacy Rate & $\begin{array}{l}\text { Literacy Rate } \\
\text { Among Males }\end{array}$ & $\begin{array}{c}\text { Literacy Rate Among } \\
\text { Females }\end{array}$ \\
\hline 1 & Kerala & 94 & 96.11 & 92.07 \\
\hline 2 & Lakhshadweep & 91.85 & 95.56 & 87.95 \\
\hline 3 & Mizoram & 91.33 & 93.35 & 89.27 \\
\hline 4 & Goa & 88.7 & 92.65 & 84.66 \\
\hline 5 & Tripura & 87.22 & 91.53 & 82.73 \\
\hline 6 & Daman and Diu & 87.1 & 91.54 & 79.55 \\
\hline 7 & $\begin{array}{l}\text { Andaman and Nicobar } \\
\text { islands }\end{array}$ & 86.63 & 90.27 & 82.43 \\
\hline 8 & Delhi & 86.21 & 90.94 & 80.76 \\
\hline 9 & Chandigarh & 86.05 & 89.99 & 81.19 \\
\hline 10 & Puducherry & 85.85 & 91.26 & 80.67 \\
\hline 11 & Himachal Pradesh & 82.8 & 89.53 & 75.93 \\
\hline 12 & Maharashtra & 82.34 & 88.38 & 75.87 \\
\hline 13 & Sikkim & 81.42 & 86.55 & 75.61 \\
\hline 14 & Tamil Nadu & 80.09 & 86.77 & 73.44 \\
\hline 15 & Nagaland & 79.55 & 82.75 & 76.11 \\
\hline 16 & Uttarakhand & 78.82 & 87.4 & 70.01 \\
\hline 17 & Gujarat & 78.03 & 85.75 & 69.68 \\
\hline 18 & Manipur & 76.94 & 83.58 & 70.26 \\
\hline 19 & West Bengal & 76.26 & 81.69 & 70.54 \\
\hline 20 & Dadra and Nagar Haveli & 76.24 & 85.17 & 64.32 \\
\hline 21 & Punjab & 75.84 & 80.44 & 70.73 \\
\hline 22 & Haryana & 75.55 & 84.06 & 65.94 \\
\hline 23 & Karnataka & 75.36 & 82.47 & 68.08 \\
\hline 24 & Meghalaya & 74.43 & 75.95 & 72.89 \\
\hline 25 & Orissa & 72.87 & 81.59 & 64.01 \\
\hline 26 & Assam & 72.19 & 77.85 & 66.27 \\
\hline 27 & Chattisgarh & 70.28 & 80.27 & 60.24 \\
\hline 28 & Madhya Pradesh & 69.32 & 78.73 & 59.24 \\
\hline 29 & Uttar Pradesh & 67.68 & 77.28 & 57.18 \\
\hline 30 & Jammu and Kashmir & 67.16 & 76.75 & 56.43 \\
\hline 31 & Andhra Pradesh & 67.02 & 74.88 & 59.15 \\
\hline 32 & Jharkhand & 66.41 & 76.84 & 55.42 \\
\hline 33 & Rajasthan & 66.11 & 79.19 & 52.12 \\
\hline 34 & Arunachal Pradesh & 65.38 & 72.55 & 57.7 \\
\hline \multirow[t]{2}{*}{35} & Bihar & 61.8 & 71.2 & 51.5 \\
\hline & India (Aggregate) & 74.04 & 82.14 & 65.46 \\
\hline
\end{tabular}


Table 17:- Gender Parity Index (GPI) for all categories of students

\begin{tabular}{|c|c|c|c|c|c|c|c|}
\hline $\begin{array}{l}\text { Level/ } \\
\text { Year }\end{array}$ & $\begin{array}{c}\text { Primary } \\
(\text { I-V) }\end{array}$ & $\begin{array}{c}\text { Upper } \\
\text { Primary } \\
\text { (VI-VIII) }\end{array}$ & $\begin{array}{c}\text { Elementary } \\
\text { (I-VIII) }\end{array}$ & $\begin{array}{l}\text { Secondary } \\
(I X-X)\end{array}$ & $\begin{array}{c}\text { Senior } \\
\text { Secondary } \\
\text { (XI-XII) }\end{array}$ & $\begin{array}{l}\text { (IX- } \\
\text { XII) }\end{array}$ & $\begin{array}{c}\text { Higher } \\
\text { Education }\end{array}$ \\
\hline 1950-51 & 0.41 & 0.22 & 0.38 & NA & NA & NA & NA \\
\hline 1960-61 & 0.5 & 0.34 & 0.47 & NA & NA & NA & NA \\
\hline 1970-71 & 0.63 & 0.45 & 0.59 & NA & NA & NA & NA \\
\hline 1980-81 & 0.67 & 0.53 & 0.63 & NA & NA & NA & NA \\
\hline 1990-91 & 0.75 & 0.61 & 0.71 & NA & NA & NA & NA \\
\hline 2000-01 & 0.82 & 0.75 & 0.8 & NA & NA & NA & NA \\
\hline 2005-06 & 0.94 & 0.88 & 0.92 & 0.8 & 0.8 & 0.8 & 0.69 \\
\hline 2006-07 & 0.94 & 0.9 & 0.93 & 0.81 & 0.83 & 0.82 & 0.69 \\
\hline 2007-08 & 0.98 & 0.91 & 0.96 & 0.85 & 0.84 & 0.85 & 0.7 \\
\hline 2008-09 & 0.99 & 0.93 & 0.97 & 0.86 & 0.85 & 0.85 & 0.72 \\
\hline 2009-10 & 1 & 0.94 & 0.98 & 0.88 & 0.87 & 0.88 & 0.74 \\
\hline 2010-11 & 1.01 & 0.95 & 0.99 & 0.88 & 0.86 & 0.87 & 0.86 \\
\hline 2011-12 & 1.01 & 0.99 & 1 & 0.93 & 0.92 & 0.93 & 0.88 \\
\hline 2012-13 & 1.03 & 1.05 & 1.03 & 0.99 & 0.98 & 0.99 & 0.89 \\
\hline 2013-14 & 1.03 & 1.06 & 1.04 & 1 & 1 & 1 & NA \\
\hline \multicolumn{8}{|c|}{ SOURCE: } \\
\hline \multicolumn{8}{|c|}{ 1. Publication Statistics of School Education. } \\
\hline \multicolumn{8}{|c|}{ 2. U-DISE-NUEPA. } \\
\hline \multicolumn{8}{|c|}{ 3. Statistics of Higher and Technical Education Publication. } \\
\hline \multicolumn{8}{|c|}{ 4. AISHE. } \\
\hline
\end{tabular}

NOTE: NA: Not Available.

Table 18:- Mortality rate in India

\begin{tabular}{|l|l|l|l|}
\hline Year & $\begin{array}{l}\text { Mortality rate, under-5,combined } \\
\text { (per 1,000) }\end{array}$ & $\begin{array}{l}\text { Mortality rate, under-5, female } \\
\text { (per 1,000) }\end{array}$ & $\begin{array}{l}\text { Mortality rate, under-5, male } \\
\text { (per 1,000) }\end{array}$ \\
\hline 1990 & 125.8 & 130 & 121.8 \\
\hline 2000 & 91.2 & 96.1 & 86.6 \\
\hline 2010 & 59.9 & 62.9 & 57 \\
\hline 2015 & 47.7 & 49.2 & 46.3 \\
\hline
\end{tabular}

SOURCE: Estimates Developed by the UN Inter-agency Group for Child Mortality Estimation (UNICEF, WHO,

World Bank, UN DESA Population Division).

Table 19:- Prevalence of over-weight among males and females

\begin{tabular}{|l|l|l|l|}
\hline Year & $\begin{array}{l}\text { Prevalence of overweight, } \\
\text { weight for height (\% of } \\
\text { children under 5) }\end{array}$ & $\begin{array}{l}\text { Prevalence of overweight, } \\
\text { weight for height, female (\%) } \\
\text { of children under 5) }\end{array}$ & $\begin{array}{l}\text { Prevalence of overweight, } \\
\text { weight for height, male }(\boldsymbol{\%} \\
\text { of children under 5) }\end{array}$ \\
\hline 1992 & $3.2 \%$ & $3.09 \%$ & $3.2 \%$ \\
\hline 1999 & $3.59 \%$ & $3.29 \%$ & $3.9 \%$ \\
\hline 2006 & $1.89 \%$ & $1.7 \%$ & $2.2 \%$ \\
\hline SOURCE: World Health Organisation, Global Database on Child Growth and Malnutrition. \\
\hline
\end{tabular}

Table 20:- Key indicators for India from National Family Health Survey-3 [NFHS-3]

\begin{tabular}{|c|c|c|c|c|}
\hline Sr. No. & Key Indicators & $\begin{array}{c}\text { NFHS-3 } \\
(\mathbf{2 0 0 5 - 2 0 0 6})\end{array}$ & Urban & Rural \\
\hline 1$)$ & Marriage and Fertility & & & \\
\hline & Women age (20-24) married by the age 18 (\%) & 47.4 & 29.3 & 56.2 \\
\hline & Men age (25-29) married by the age 18 (\%) & 32.3 & 18.1 & 40.3 \\
\hline & Family Planning (currently married women, age 15-49 yrs.) & & & \\
\hline 2$)$ & Female sterilisation (\%) & 37.3 & 37.8 & 37.1 \\
\hline
\end{tabular}




\begin{tabular}{|c|l|c|c|c|}
\hline & Male sterilisation (\%) & 1 & 1.1 & 1 \\
\hline & \multicolumn{1}{|c|}{ Anaemia among adults } & & \\
\hline 3$)$ & \multicolumn{1}{|c|}{ Nutritional Status of ever-married adults (age 15-49) } & & & \\
\hline & Women whose Body Mass Index is below normal (\%) & 33 & 19.8 & 38.8 \\
\hline & Men whose Body Mass Index is below normal (\%) & 28.1 & 17.5 & 33.1 \\
\hline & \multicolumn{1}{|c|}{} & & \\
\hline 4$)$ & \multicolumn{1}{|c|}{ yrs.) } & & & \\
\hline & Ever-married women age 15-49 yrs. who are anaemic (\%) & 56.2 & 51.5 & 58.2 \\
\hline & Ever-married men age 15-49 yrs. who are anaemic (\%) & 24.3 & 17.2 & 27.7 \\
\hline 5$)$ & Knowledge of HIV/AIDS among ever-married adults (15-49 & & \\
\hline & Women who've heard of AIDS (\%) & 57 & 80.7 & 46.4 \\
\hline & Men who've heard of AIDS (\%) & 94.2 & 73 \\
\hline & $\begin{array}{l}\text { Women who know that consistent condom use can reduce the } \\
\text { chances of getting HIV/AIDS (\%) }\end{array}$ & 34.7 & 56.3 & 25.1 \\
\hline & $\begin{array}{l}\text { Men who know that consistent condom use can reduce the } \\
\text { chances of getting HIV/AIDS (\%) }\end{array}$ & 68.1 & 85.6 & 59.5 \\
\hline & & & \\
\hline
\end{tabular}

\begin{tabular}{|c|c|c|c|c|c|c|c|c|c|c|c|c|}
\hline $\begin{array}{l}\text { CR } \\
\mathrm{IM} \\
\mathrm{E} \\
\mathrm{HE} \\
\mathrm{AD} \\
\mathrm{S} \\
\rightarrow\end{array}$ & $\begin{array}{l}\text { Rape } \\
\text { (in } \\
\text { no.) }\end{array}$ & $\begin{array}{l}\text { Kidna } \\
\text { pping } \\
\text { and } \\
\text { Abduc } \\
\text { tion of } \\
\text { Wome } \\
\text { n \& } \\
\text { Girls } \\
\text { (in } \\
\text { no.) }\end{array}$ & $\begin{array}{l}\text { Dowry } \\
\text { Deaths } \\
\text { (in } \\
\text { no.) }\end{array}$ & $\begin{array}{l}\text { Assau } \\
\text { lt on } \\
\text { wome } \\
\text { n with } \\
\text { intent } \\
\text { to } \\
\text { outrag } \\
\text { e her } \\
\text { modes } \\
\text { ty } \\
\text { (in } \\
\text { no.) }\end{array}$ & $\begin{array}{l}\text { Insult } \\
\text { to the } \\
\text { modes } \\
\text { ty of } \\
\text { Wome } \\
\text { n } \\
\text { (in } \\
\text { no.) }\end{array}$ & $\begin{array}{l}\text { Cruelt } \\
\text { y by } \\
\text { Husba } \\
\text { nd or } \\
\text { his } \\
\text { relativ } \\
\text { es (in } \\
\text { no.) }\end{array}$ & $\begin{array}{l}\text { Impo } \\
\text { rtatio } \\
\mathrm{n} \text { of } \\
\text { Girls } \\
\text { from } \\
\text { Forei } \\
\text { gn } \\
\text { Coun } \\
\text { try } \\
\text { (in } \\
\text { no.) }\end{array}$ & $\begin{array}{l}\text { Cases } \\
\text { regist } \\
\text { ered } \\
\text { under } \\
\text { Immo } \\
\text { ral } \\
\text { Traffi } \\
\text { c (P) } \\
\text { Act } \\
\text { (in } \\
\text { no.) }\end{array}$ & $\begin{array}{l}\text { Cases } \\
\text { regist } \\
\text { ered } \\
\text { under } \\
\text { Dowr } \\
\text { y } \\
\text { Prohi } \\
\text { bition } \\
\text { Act } \\
\text { (in } \\
\text { no.) }\end{array}$ & $\begin{array}{l}\text { Cases } \\
\text { registe } \\
\text { red } \\
\text { under } \\
\text { Indece } \\
\text { nt } \\
\text { Repres } \\
\text { entatio } \\
n \text { of } \\
\text { Wome } \\
n(P) \\
\text { Act (in } \\
\text { no.) }\end{array}$ & $\begin{array}{l}\text { Cases } \\
\text { regist } \\
\text { ered } \\
\text { under } \\
\text { Com } \\
\text { missi } \\
\text { on of } \\
\text { Sati } \\
\text { (P) } \\
\text { Act } \\
\text { (in } \\
\text { no.) }\end{array}$ & $\begin{array}{l}\text { Total } \\
\text { Crimes } \\
\text { against } \\
\text { Wome } \\
\text { n (in } \\
\text { no.) }\end{array}$ \\
\hline $\begin{array}{l}200 \\
1\end{array}$ & 16075 & 14645 & 6851 & 34124 & 9746 & 49170 & 114 & 8796 & 3222 & 1052 & 0 & $\begin{array}{l}14379 \\
5\end{array}$ \\
\hline $\begin{array}{l}200 \\
2\end{array}$ & $\begin{array}{l}16373 \\
(1.85)\end{array}$ & $\begin{array}{l}14506 \\
(- \\
0.95)\end{array}$ & $\begin{array}{l}6822 \\
(-0.42)\end{array}$ & $\begin{array}{l}33943 \\
(- \\
0.53)\end{array}$ & $\begin{array}{l}10155 \\
(4.20)\end{array}$ & $\begin{array}{l}49237 \\
(0.14)\end{array}$ & $\begin{array}{l}76(- \\
24.99 \\
)\end{array}$ & $\begin{array}{l}6598 \\
(- \\
12.60)\end{array}$ & $\begin{array}{l}2816 \\
(- \\
12.60)\end{array}$ & $\begin{array}{l}2508 \\
(138.4 \\
0)\end{array}$ & 0 & $\begin{array}{l}14303 \\
4(- \\
0.53)\end{array}$ \\
\hline $\begin{array}{l}200 \\
3\end{array}$ & $\begin{array}{l}15847 \\
(- \\
3.21) \\
\end{array}$ & $\begin{array}{l}13296 \\
(- \\
8.34) \\
\end{array}$ & $\begin{array}{l}6208 \\
(-9.00)\end{array}$ & $\begin{array}{l}32939 \\
(- \\
2.96) \\
\end{array}$ & $\begin{array}{l}12325 \\
(21.37 \\
) \\
\end{array}$ & $\begin{array}{l}50703 \\
(2.98)\end{array}$ & $\begin{array}{l}46(- \\
16.49 \\
)\end{array}$ & $\begin{array}{l}5510 \\
(- \\
4.69) \\
\end{array}$ & $\begin{array}{l}2684 \\
(- \\
4.69) \\
\end{array}$ & $\begin{array}{l}1043 \\
(- \\
58.41)\end{array}$ & 0 & $\begin{array}{l}14060 \\
1(- \\
1.70)\end{array}$ \\
\hline $\begin{array}{l}200 \\
4\end{array}$ & $\begin{array}{l}18233 \\
(15.06 \\
)\end{array}$ & $\begin{array}{l}15578 \\
(17.16 \\
)\end{array}$ & $\begin{array}{l}7026 \\
(13.18 \\
)\end{array}$ & $\begin{array}{l}34567 \\
(4.94)\end{array}$ & $\begin{array}{l}10001 \\
(- \\
18.86)\end{array}$ & $\begin{array}{l}58121 \\
(14.63 \\
)\end{array}$ & $\begin{array}{l}89 \\
(4.32 \\
)\end{array}$ & $\begin{array}{l}5748 \\
(33.83 \\
)\end{array}$ & $\begin{array}{l}3592 \\
(33.83 \\
)\end{array}$ & $\begin{array}{l}l 378 \\
(32.12 \\
)\end{array}$ & 0 & $\begin{array}{l}15433 \\
3 \\
(9.77)\end{array}$ \\
\hline $\begin{array}{l}200 \\
5\end{array}$ & $\begin{array}{l}18359 \\
(0.69)\end{array}$ & $\begin{array}{l}15750 \\
(1.10)\end{array}$ & $\begin{array}{l}6787 \\
(-3.40)\end{array}$ & $\begin{array}{l}34175 \\
(- \\
1.13) \\
\end{array}$ & $\begin{array}{l}9984 \\
(-0.17)\end{array}$ & $\begin{array}{l}58319 \\
(0.34)\end{array}$ & $\begin{array}{l}149 \\
(2.78 \\
)\end{array}$ & $\begin{array}{l}5908 \\
(- \\
10.80)\end{array}$ & $\begin{array}{l}3204 \\
(- \\
10.80)\end{array}$ & $\begin{array}{l}2917 \\
(111.6 \\
8)\end{array}$ & 1 & $\begin{array}{l}15555 \\
3 \\
(0.79)\end{array}$ \\
\hline $\begin{array}{l}200 \\
6\end{array}$ & $\begin{array}{l}19348 \\
(5.39)\end{array}$ & $\begin{array}{l}17414 \\
(10.57 \\
)\end{array}$ & $\begin{array}{l}7618 \\
(12.24 \\
)\end{array}$ & $\begin{array}{l}36617 \\
(7.15)\end{array}$ & $\begin{array}{l}9966 \\
(-0.18)\end{array}$ & $\begin{array}{l}63128 \\
(8.25)\end{array}$ & $\begin{array}{l}67(- \\
23.14 \\
)\end{array}$ & $\begin{array}{l}4541 \\
(40.57 \\
)\end{array}$ & $\begin{array}{l}4504 \\
(40.57 \\
)\end{array}$ & $\begin{array}{l}1562 \\
(- \\
46.45)\end{array}$ & 0 & $\begin{array}{l}16476 \\
5 \\
(5.92)\end{array}$ \\
\hline $\begin{array}{l}200 \\
7\end{array}$ & $\begin{array}{l}20737 \\
(7.18)\end{array}$ & $\begin{array}{l}20416 \\
(17.24 \\
)\end{array}$ & $\begin{array}{l}8093 \\
(6.24)\end{array}$ & $\begin{array}{l}38734 \\
(5.78)\end{array}$ & $\begin{array}{l}10950 \\
(9.87)\end{array}$ & $\begin{array}{l}75930 \\
(20.28 \\
)\end{array}$ & $\begin{array}{l}61(- \\
21.43 \\
)\end{array}$ & $\begin{array}{l}3568 \\
(24.84 \\
)\end{array}$ & $\begin{array}{l}5623 \\
(24.84 \\
)\end{array}$ & $\begin{array}{l}1200 \\
(- \\
23.18)\end{array}$ & 0 & $\begin{array}{l}18531 \\
2 \\
(12.47)\end{array}$ \\
\hline $\begin{array}{l}200 \\
8\end{array}$ & $\begin{array}{l}21467 \\
(3.52)\end{array}$ & $\begin{array}{l}22939 \\
(12.36\end{array}$ & $\begin{array}{l}8172 \\
(0.98)\end{array}$ & $\begin{array}{l}40413 \\
(4.33)\end{array}$ & $\begin{array}{l}12214 \\
(11.54\end{array}$ & $\begin{array}{l}81344 \\
(7.13)\end{array}$ & $\begin{array}{l}67(- \\
25.45\end{array}$ & $\begin{array}{l}2660 \\
(-\end{array}$ & $\begin{array}{l}5555 \\
(-\end{array}$ & $\begin{array}{l}1025 \\
(-\end{array}$ & 1 & $\begin{array}{l}19585 \\
7\end{array}$ \\
\hline
\end{tabular}




\begin{tabular}{|c|c|c|c|c|c|c|c|c|c|c|c|c|}
\hline & & ) & & & ) & & ) & 1.21) & 1.21) & 14.58) & & (5.69) \\
\hline $\begin{array}{l}200 \\
9\end{array}$ & $\begin{array}{l}21397 \\
(- \\
0.33)\end{array}$ & $\begin{array}{l}25741 \\
(12.22 \\
)\end{array}$ & $\begin{array}{l}8383 \\
(2.58)\end{array}$ & $\begin{array}{l}38711 \\
(- \\
4.21)\end{array}$ & $\begin{array}{l}11009 \\
(-9.87)\end{array}$ & $\begin{array}{l}89546 \\
(10.08 \\
)\end{array}$ & $\begin{array}{l}48(- \\
6.99)\end{array}$ & $\begin{array}{l}2474 \\
(1.71)\end{array}$ & $\begin{array}{l}5650 \\
(1.71)\end{array}$ & $\begin{array}{l}845(- \\
17.56)\end{array}$ & 0 & $\begin{array}{l}20380 \\
4 \\
(4.06)\end{array}$ \\
\hline $\begin{array}{l}201 \\
0\end{array}$ & $\begin{array}{l}22172 \\
(3.62)\end{array}$ & $\begin{array}{l}29795 \\
(15.75 \\
) \\
\end{array}$ & $\begin{array}{l}8391 \\
(0.10)\end{array}$ & $\begin{array}{l}40613 \\
(4.91)\end{array}$ & $\begin{array}{l}9961 \\
(-9.52)\end{array}$ & $\begin{array}{l}94041 \\
(5.02)\end{array}$ & $\begin{array}{l}36 \\
(1.01 \\
) \\
\end{array}$ & $\begin{array}{l}2499 \\
(- \\
8.28) \\
\end{array}$ & $\begin{array}{l}5182 \\
(- \\
8.28) \\
\end{array}$ & $\begin{array}{l}895 \\
(5.92)\end{array}$ & 0 & $\begin{array}{l}21358 \\
5 \\
(4.80)\end{array}$ \\
\hline $\begin{array}{l}201 \\
1\end{array}$ & $\begin{array}{l}24206 \\
(9.17)\end{array}$ & $\begin{array}{l}35565 \\
(19.37 \\
)\end{array}$ & $\begin{array}{l}8618 \\
(2.71)\end{array}$ & $\begin{array}{l}42968 \\
(5.80)\end{array}$ & $\begin{array}{l}8570 \\
(- \\
13.92)\end{array}$ & $\begin{array}{l}99135 \\
(5.42)\end{array}$ & $\begin{array}{l}80(- \\
2.56)\end{array}$ & $\begin{array}{l}2435 \\
(27.73 \\
)\end{array}$ & $\begin{array}{l}6619 \\
(27.73 \\
)\end{array}$ & $\begin{array}{l}453(- \\
49.39)\end{array}$ & 1 & $\begin{array}{l}22865 \\
0 \\
(7.05)\end{array}$ \\
\hline $\begin{array}{l}201 \\
2\end{array}$ & $\begin{array}{l}24923 \\
(2.96)\end{array}$ & $\begin{array}{l}38262 \\
(7.58)\end{array}$ & $\begin{array}{l}8233 \\
(-4.47)\end{array}$ & $\begin{array}{l}45351 \\
(5.55)\end{array}$ & $\begin{array}{l}9173 \\
(7.04)\end{array}$ & $\begin{array}{l}10652 \\
7 \\
(7.46)\end{array}$ & $\begin{array}{l}59 \\
(5.26 \\
) \\
\end{array}$ & $\begin{array}{l}2563 \\
(36.55 \\
)\end{array}$ & $\begin{array}{l}9038 \\
(36.55 \\
)\end{array}$ & $\begin{array}{l}141(- \\
68.87)\end{array}$ & 0 & $\begin{array}{l}24427 \\
0 \\
(6.83)\end{array}$ \\
\hline $\begin{array}{l}\text { SOU } \\
\text { (OG } \\
\text { NOT } \\
\text { year }\end{array}$ & $\begin{array}{l}\text { CE: D } \\
\text { Platf } \\
\text { Figu } \\
\text { owth }\end{array}$ & $\begin{array}{l}\text { base o } \\
\text { n India } \\
\text { in pare } \\
\text { es }\end{array}$ & $\mathrm{G}$ & mer & & & & & & & & \\
\hline
\end{tabular}

Table 21:- Crimes against women in India

\section{Notes:-}

1. Women in ministerial level positions are the proportion of women in ministerial or equivalent positions (including deputy prime ministers) in the government. Prime Ministers/ Heads of government are included when they hold ministerial portfolios. Vice-Presidents and heads of governmental or public agencies are excluded from this definition.

2. Gross Enrolment Ratio (GER) is a statistical measure to determine the number of students enrolled in school at different grade levels. GER is the ratio of the number of students who are actually enrolled in schools to the number of children who are of corresponding school enrolment age.

3. Gender Parity Index (GPI) is a socioeconomic index usually designed to measure the relative access to education of males and females. In its simplest form, it is calculated as the quotient of the number of females by the number of males enrolled in a given stage of education (primary, secondary etc.). GPI reflects females' access to education as compared to that of males. This is calculated for each school phase. A GPI of less than 1 indicates that there are fewer females than males in the formal education system in proportion to the appropriate school-age population and more than 1 means that there are proportionately more girls than boys attending school and a score of 1 reflects equal enrolment rates for boys and girls.

\section{References:-}

1. Dewey, J (1963) Democracy and Education: An Introduction to the Philosophy of Education (New York: Macmillan.)

2. Garikipati, S (2009) "Landless but not Assetless: Female Agricultural Labour on the Road to Better Status, Evidence from India" Journal of Peasant Studies, Volume 36, No.3, pp. 517-545.

3. George, S, Abel, R and Miller B D (1992, May 30) "Female Infanticide in Rural South India" Economic and Political Weekly, Volume 27, No. 22, pp.1153-1156.

4. Jose, S (2011, July 16) "Adult Undernutrition in India: Is There a Huge Gender Gap?" Economic and Political Weekly, Volume XLVI, No. 29, pp. 95-102.

5. Kamalapur, S M and Reddy, S (2013) "Women Health in India: An Analysis" International Research Journal of Social Sciences, Volume 2, No. 10, pp. 11-15. Retrieved from http://www.isca.in/IJSS/Archive/v2/i10/3.ISCAIRJSS-2013-135.pdf on March 3, 2016.

6. Mahesh, J (2010) Political Empowerment of Women with Reference to Panchayati Raj Institutions: A Case of Udupi District (Ph.D Thesis), Manipal University, Manipal. Retrieved from http://shodhganga.inflibnet.ac.in/handle/10603/2392 on March 3, 2016.

7. Mehrotra, S (2006, March 11) "Child Malnutrition and Gender Discrimination in South Asia" Economic and Political Weekly, Volume XLI No.10, pp. 912-918.

8. Mazumdar, I, Neetha, N and Agnihotri, I (2013, March 9) "Migration and Gender in India" Economic and Political Weekly, Volume XLVII, No.10, pp. 54-64. 
9. Pandey, A P (2006) “Gender Disparities in Education-needs Community Participation" MPRA paper. Retieved from http://mpra.ub.uni-muenchen.de/622/.

10. Paul, T and Raju, S (2014, July 19) "Gendered labour in India: Diversified or confined?" Economic and Political Weekly, Volume XLIX, No. 29, pp. 197-208.

11. Sengupta, A and Das, P (2014, May 24) "Gender Wage Discrimination Across Social and Religious Groups in India: Estimates with Unit Level Data" Economic and Political Weekly, Volume XLIX, No. 21, pp. 71-76.

12. Sethuraman, K and Duvvury, N (2007, November 3) "The Nexus of Gender Discrimination with Malnutrition: An introduction" Review of Women Studies, Economic and Political Weekly, Volume 42, No. 44, pp. 49-53.

13. Sharma, P (2015, November 7) "Gender-based Crime and Gender Inequality in India: A Subnational Analysis" Economic and Political Weekly. Volume L, No.45, pp. 48-53.

14. Shijith, V P and Sekher, T V (2015, November 21) "Culture, Gender Bias and Beliefs Surrounding the 'Nakusa' Girls of Maharashtra" Economic and Political Weekly, Volume L, No. 46 \& 47, pp. 75-78.

15. Swaminathan, H, Lahoti, R and Suchitra, J Y (2012, September 1) "Gender Asset and Wealth Gaps: Evidence from Karnataka" Economic and Political Weekly, Volume XLVII, No.35, pp. 59-67.

16. Thirlwall, A P (1972) Growth and Development with Special Reference to Developing Economies ( ${ }^{\text {th }}$ Ed.) (London: Palgrave Macmillan)

17. Todaro, M P and Smith, S C (2003) Economic Development ( $8^{\text {th }}$ Ed) (New Delhi: Pearson Education Ltd.)

\section{Webliography:-}

1. www.censusindia.gov.in (Accessed on January 30, 2016).

2. www.childmortality. org (Accessed on February 10, 2016).

3. www.data.worldbank.org (Accessed on February 5, 2016).

4. https://data.gov.in/catalog/crime-committed-against women (Accessed on February8, 2016).

5. www.ipu.org (accessed on February 7, 2016).

6. www.indiastat.com (Accessed on November 30, 2015).

7. www.labour.nic.in (Accessed on November 27, 2015).

8. www.mospi.nic.in (Accessed on December 12, 2015).

9. www.un.org/millenniumgoals/ (Accessed on February 7, 2016).

10. www.wikipedia. com (Accessed on February 24, 2016).

11. http://www.childrencount.org.za/ (Accessed on March 11, 2016).

12. http://www.iwraw-ap.org/ (Accessed on April 11, 2016).

13. http://rchiips.org/ (Accessed on April 12, 2016). 